\title{
Protective Effect of Genistein on the Morphine-Induced Kidney Disorders in Male Mice
}

\author{
Cyrus Jalili ${ }^{1,2}$, Iraj Rashidi ${ }^{2}$, Shiva Roshankhah ${ }^{2}$, Faramarz Jalili ${ }^{3}$, Mohammad Reza Salahshoor ${ }^{2^{*}}$
}

\begin{abstract}
${ }^{1}$ Medical Biology Research Center, Department of Anatomical Sciences, Kermanshah University of Medical Sciences, Kermanshah, IRAN
${ }^{2}$ Department of Anatomical Sciences, Medical School, Kermanshah University of Medical Sciences, Kermanshah, IRAN

${ }^{3}$ Students research committee, Department of Anatomical Sciences, Kermanshah university of Medical Sciences Kermanshah, IRAN

*Corresponding Author: reza.salahshoor@yahoo.com
\end{abstract}

Citation: Jalili C, Rashidi I, Roshankhah S, Jalili F, Salahshoor MR. Protective Effect of Genistein on the Morphine-Induced Kidney Disorders in Male Mice. Electron J Gen Med. 2020;17(3):em213. https://doi.org/10.29333/ejgm/7874

\section{ARTICLE INFO}

Received: 22 Nov. 2019

Accepted: 3 Feb. 2020

\begin{abstract}
Background: Morphine is a member of the naturally occurring phenanthrene alkaloids of opium. Genistein is a phytoestrogen, present in soy products. This study was designed to evaluate protective effects of genistein against morphine induced damages to the kidneys of mice.
\end{abstract}

Methods: In this study, 48 male mice were randomly assigned to 8 groups: control (saline), morphine treated group (10 mg/kg/day); genistein groups (1, 2, $4 \mathrm{mg} / \mathrm{kg} /$ day) and morphine plus genistein treated group. Drugs were administrated intraperitoneally for 30 consequent days. Weight of animals and kidneys, glomeruli characteristics, kidney function markers and blood serum nitric oxide level has been studied.

Result: The results indicated that morphine administration significantly increased Lactate dehydrogenase (LDH), Blood urea nitrogen (BUN), creatinine and nitric oxide levels compared to the control ( saline) group $(P<0.05)$. Genistein in all doses and genistein plus morphine at the dose of $4 \mathrm{mg} / \mathrm{kg}$ significantly decreased LDH, BUN, creatinine, glomerular diameter and nitric oxide levels compared to the control and morphine groups $(p<0.05)$.

Conclusion: It seems that genistein administration improved kidney damages induced by morphine in mice.

Keywords: morphine, genistein, kidney

\section{INTRODUCTION}

Human familiarity with narcotics is not known exactly, but human attention has always been drawn to the power of opioid analgesic drugs such as opium. Chronic use of opioids causes two major problems, endurance and dependency (1). Morphine is the main material of opium latex (2). While its indiscriminate use has undesirable effects such as respiratory depression and destruction, addiction, coma and death (3). Free radicals and oxidative stress are increase as a result of using morphine (4). Liver and kidney are the main organs for metabolism and excretion of toxins through urine and feces (5). Given that, a major part of the foreign substances entering the body, including drugs, are metabolized by the liver hepatocytes and are excreted by the kidney cells. It is possible that during metabolism, waste products damage liver and kidney cells (6). Opioids reduce kidney function through renal plasma flow reduction (7). Nitric oxide (NO) is a pleiotropic signaling molecule which is considered a vascular homeostasis regulator and blood pressure controller in biological systems (8). Increased NO production induces various diseases (9). It has been shown that NO production is increased with morphine consumption (10). Phytoestrogens are compounds found in some edible plants and grains. Genistein phytoestrogen exists particularly in soybeans. Although these compounds are not steroidal, they act similar to estrogen (11). Today, regarding the results of epidemiological studies on the role of soy in inhibiting breast cancer (12) and cardiovascular disease and controlling blood sugar in diabetics, the food products containing soy in different ways have gained a special place in the diet of people (13). The positive effects of soy or soy components on inflammatory markers and oxidative stress have also been proven (14). Use of medicinal plants and herbal medicines in different countries is increasing because of the effectiveness of these substances demonstrated in the scientific community $(15,16)$. Considering the side effects of some chemical drugs, more attention is required to be paid to the possible effects of medicinal plants on the performance of different parts of the body. Regarding the toxic effects of morphine and genistein properties, no study has been done to evaluate the protective effects of genistein on the morphineinduced damages in the kidney. This study was designed to investigate the protective effects of genistein on morphineinduced damage in kidneys.

\section{METHODS}

\section{Animal and Treatment}

Forty eight male mice Bulb/c with a weight range of 27-30 grams were purchased from Razi Institute. All animals were housed in plastic cages and kept in a conditioned atmosphere 


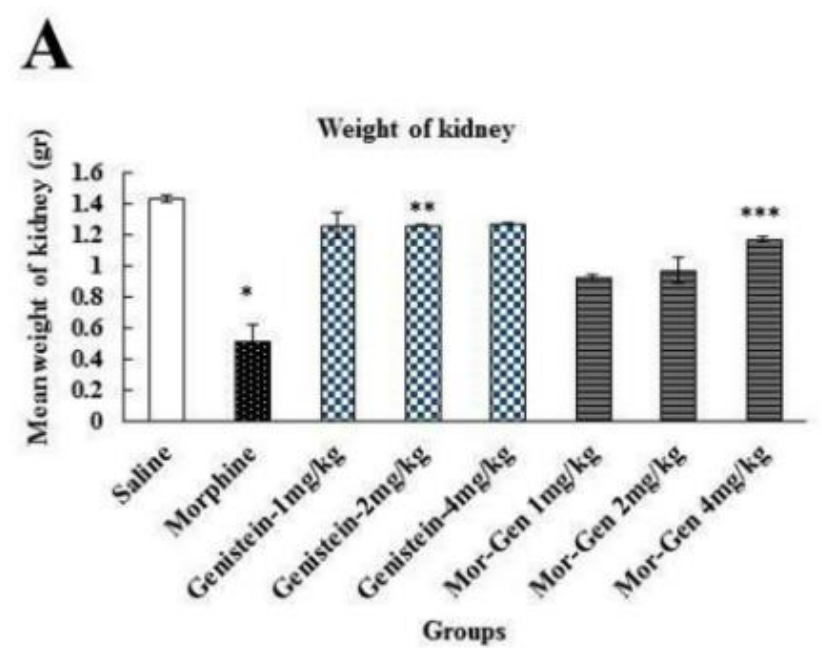

\section{B}

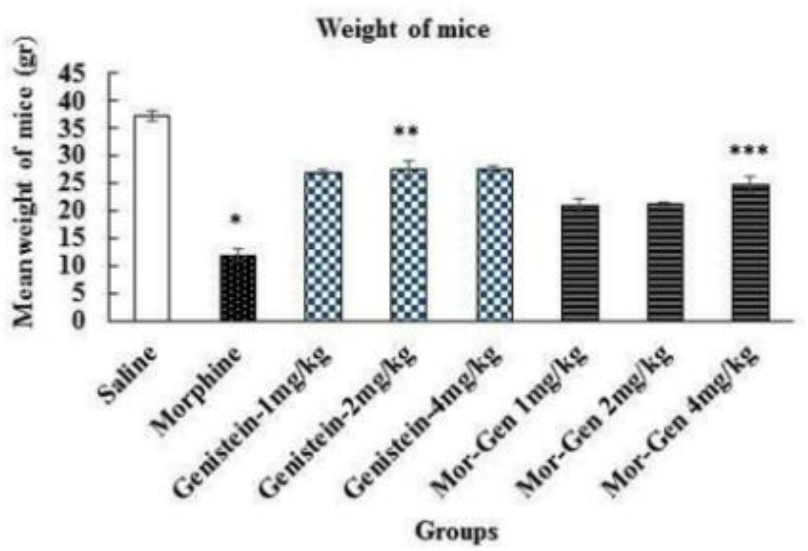

Figure 1. Mean kidney (A) and Mice (B) weight in mice receiving morphine and genistein

${ }^{\star} P<.05$ compared with the saline group.

${ }^{\star \star} P<.05$ compared with the morphine group in all doses.

${ }^{\star \star \star} P<.05$ compared with the morphine group at the dose of $4 \mathrm{mg} / \mathrm{kg}$.

at $20 \pm 2{ }^{\circ} \mathrm{C}$ with 12 -h light/dark cycles. The mice had unrestricted access to food and water. All the mice were randomly divided into eight groups (6 mice/group). Group 1 (Control group) received normal saline solution. Group 2 (positive control) received $10 \mathrm{mg} / \mathrm{kg}$ of morphine in the first day, and $2 \mathrm{mg} / \mathrm{kg}$ of morphine was added every day to the thirtieth day. Groups 3, 4 and 5 received 1,2 and $4 \mathrm{mg} / \mathrm{kg}$ of genistein, respectively. Groups 6,7 and 8 received morphine following pretreatment with genistein at doses of 1, 2 and 4 $\mathrm{mg} / \mathrm{kg}$, respectively. All animals received the drugs by intraperitoneal injection twice a day for 30 days (16).

\section{Weight of Animals and Kidneys}

The animals' weight was measured at the beginning and end of the study. Animals were killed and sacrificed. Kidneys were removed and weighed on a microbalance sensitive to $0.001 \mathrm{mg}$ (Precisa 125A, Switzerland) and average weights of the kidneys of mice were calculated and recorded (4).

\section{Glomeruli Characteristics}

Kidneys were removed and fixed in $10 \%$ formalin. Abstracted kidneys were trimmed transversely into three parts. The middle part was then immersed in $70 \%$ alcohol, followed by immersions in a series of alcohol solutions with ascending concentrations. After a dehydration process, the tissue samples were then processed further before being sectioned (5m thick) using microtome (EC350-2). Hematoxylin and eosin (H\&E) staining technique would stain the nucleus purple and the cytoplasm pink. The steps of H\&E staining technique included deparaffinization, hydration, hematoxylin and eosin staining, dehydration and clearing. Proximal and distal tubule diameter, diameter and number of glomeruli and kidney weights were examined under Olympus/3H light microscope (4).

\section{Kidney Function Markers}

The blood taken from the heart was incubated for 15 minutes at $37^{\circ} \mathrm{C}$ and was centrifuged for 15 minutes at 3000 rpm to obtain the serum. The serum samples were stored in a freezer $\left(-20^{\circ} \mathrm{C}\right)$ Lactate dehydrogenase and Blood Urea Nitrogen creatinine levels were determined by ELISA (Abcam
108666, USA) method using a specific kit (PARS -AZMON Company, IRAN) (17).

\section{Nitric Oxide}

Griess reaction was used from zinc sulfate powder to remove the serum protein of samples. For this purpose, $6 \mathrm{mg}$ of zinc sulfate powder was mixed with $400 \mu \mathrm{l}$ of serum samples in micro tubes, and microtubes were then vortexed for one minute. After mixing, samples were centrifuged for 10 minutes at 12,000 revolutions per minute $(\mathrm{rpm})$ at $4{ }^{\circ} \mathrm{C}$, and upper solution (supernatant) was used to measure NO (NOx). Briefly, $50 \mu \mathrm{l}$ of sample was added to $100 \mu \mathrm{l}$ of Griess reagent (Sigma, Germany), and the reaction mixture was incubated for about 30 $\mathrm{min}$ at room temperature to protect it from light. The optical density was measured at $450 \mathrm{~nm}$ in a microplate reader according to the reagent manufacturer's protocol (18).

\section{Statistical Analysis}

Quantitative data were expressed as mean \pm SD. Differences between groups were determined by one-way ANOVA followed by Tukey test. $\mathrm{P}<0.05$ was considered to denote statistical significance.

\section{RESULTS}

\section{Kidney and Body Weight Evaluation}

The kidney and mice weights were significantly decreased in the morphine group compared to the control group $(p<0.05)$. Further, genistein caused a significant increase in the weights in all treated groups in comparison with morphine group administration $(p<0.05)$. In the morphine plus genistein group, a significant increase in kidney and mice weights were observed at the dose of $4 \mathrm{mg} / \mathrm{kg}$ in comparison to the morphine group $(p<0.05)$ (Figure 1$)$.

\section{Measurement of Nitric Oxide Level}

Serum NO level evaluation showed a significant increase in the group receiving morphine compared to the control group $(p<0.05)$. Also, the mean of nitric oxide in blood serum decreased significantly in genistein (in all doses) and genistein 


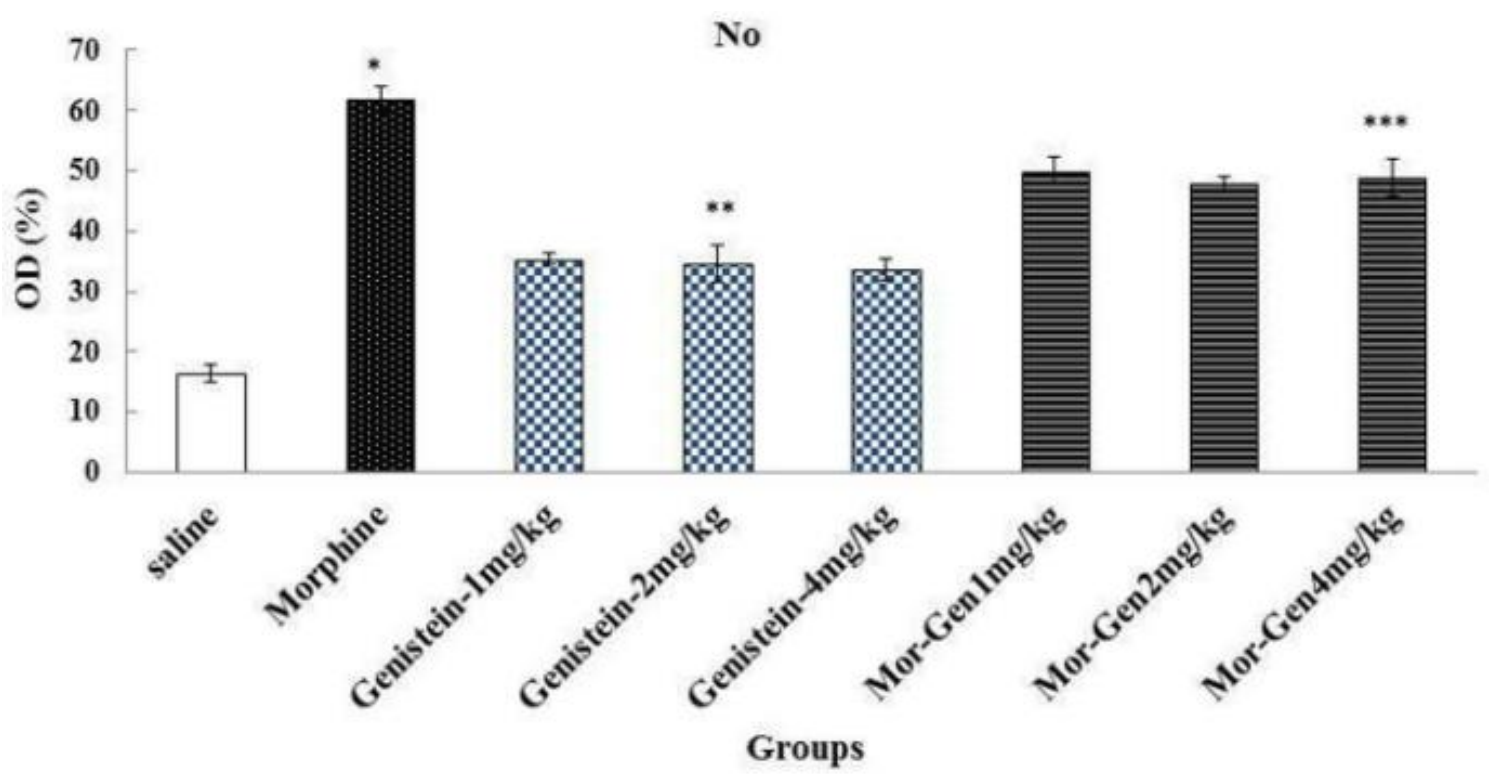

Figure 2. Nitric oxide level in mice receiving morphine and genistein

${ }^{\star} P<.05$ compared with the saline group.

${ }^{\star \star} P<.05$ compared with the morphine group in all doses.

${ }^{\star \star \star} P<.05$ compared with the morphine at the dose of $4 \mathrm{mg} / \mathrm{kg}$.
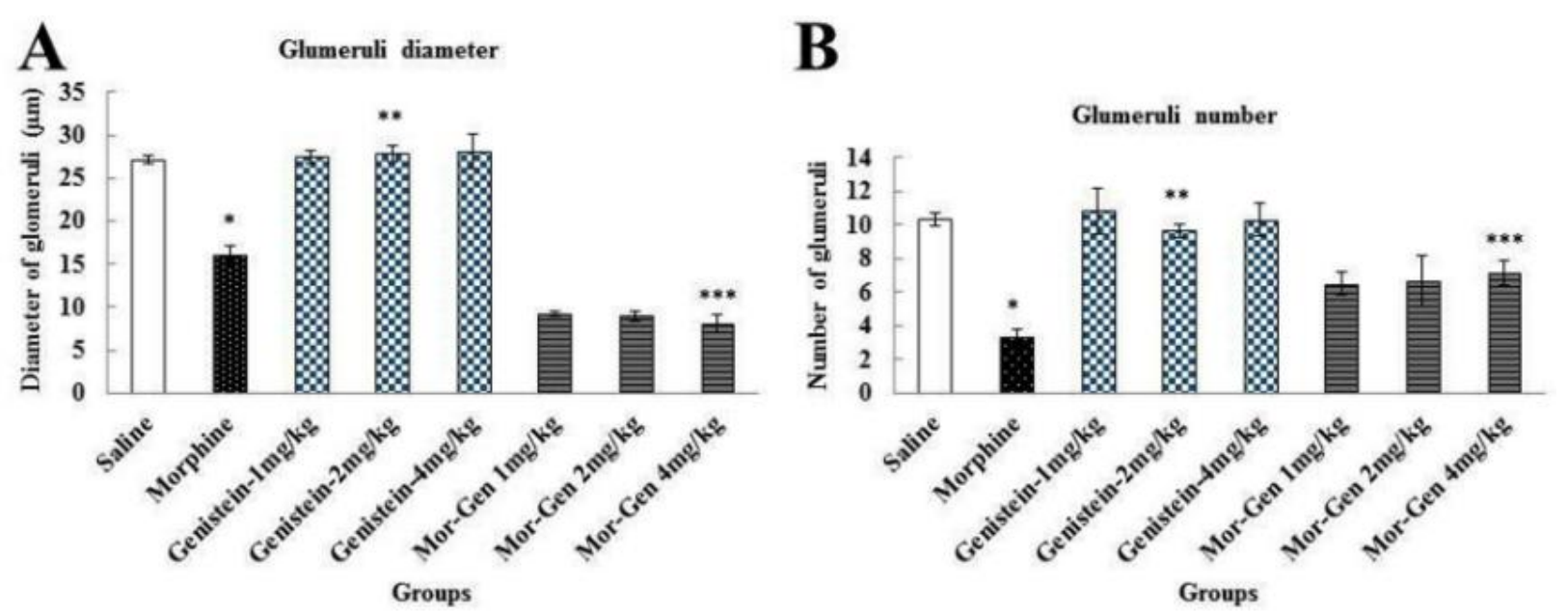

Figure 3. Glomeruli characteristics (glomerular diameter $[A]$ and number of glomeruli $[B]$ ) in mice receiving morphine and genistein

${ }^{\star} P<.05$ compared with the saline group.

${ }^{\star \star} P<.05$ compared with the morphine group in all doses.

${ }^{\star \star \star} P<.05$ compared with the morphine group at the dose of $4 \mathrm{mg} / \mathrm{kg}$.

plus morphine group (at the dose of $4 \mathrm{mg} / \mathrm{kg}$ ) compared to morphine group $(p<0.05)$ (Figure 2$)$.

\section{Measurement of Glomeruli Characteristics}

The results of mean diameter and number of glomeruli evaluation showed a significant decreased in the morphine group compared to the control (saline) group $(p<0.05)$. Furthermore, in the genistein (in all doses) and genistein plus morphine (at dose of $4 \mathrm{mg} / \mathrm{kg}$ ) groups, a significant increase was observed in the mean diameter of glomeruli and number of glomeruli compared to the morphine group $(p<0.05)$ (Figure 3).

\section{Measurement of Kidney Function Markers}

The mean of BUN, LDH and creatinine levels were found to be significantly higher in the morphine group than in control (saline) group $(p<0.05)$. Also, the mean of BUN, LDH and

creatinine in blood serum decreased significantly in genistein (in all doses) and genistein plus morphine (at dose of $4 \mathrm{mg} / \mathrm{kg}$ ) compared to morphine group ( $p<0.05$ ) (Figure 4).

\section{Kidney Histological Features}

Kidney tissue images showed glomeruli and Bowman's capsule in a specified range and health in the genistein, genistein plus morphine (at dose of $4 \mathrm{mg} / \mathrm{kg}$ ) and saline groups. More distributed leucocytes, decrease the diameter of glomeruli, shrinking glomerulus and enlargement of kidney veins were observed in the morphine group (Figure 5). 

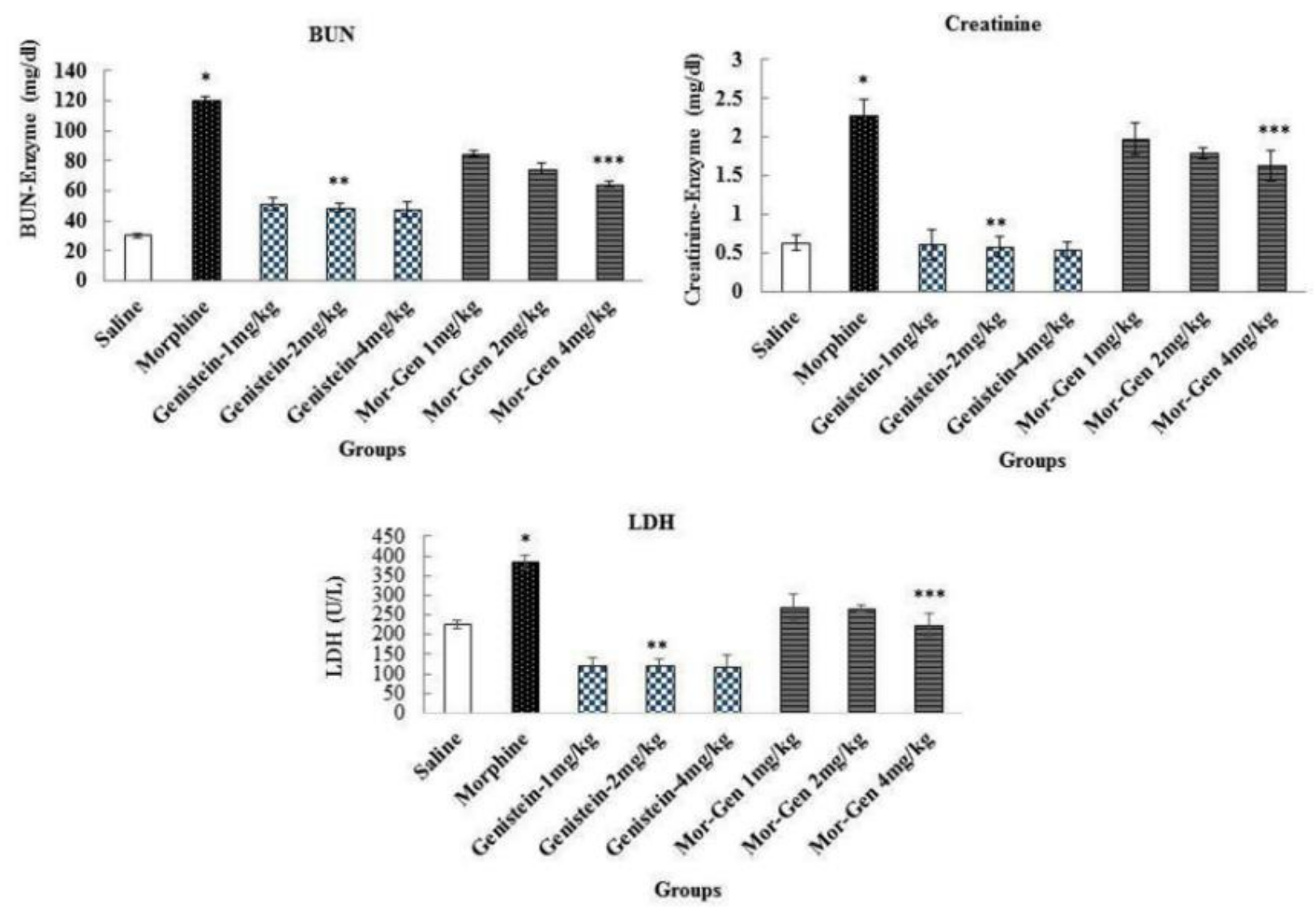

Figure 4. Kidney function markers in mice receiving morphine and genistein

${ }^{*} P<.05$ compared with the saline group.

${ }^{\star \star} P<.05$ compared with the morphine group in all doses.

${ }^{* \star \star} P<.05$ compared with the morphine group at the dose of $4 \mathrm{mg} / \mathrm{kg}$.

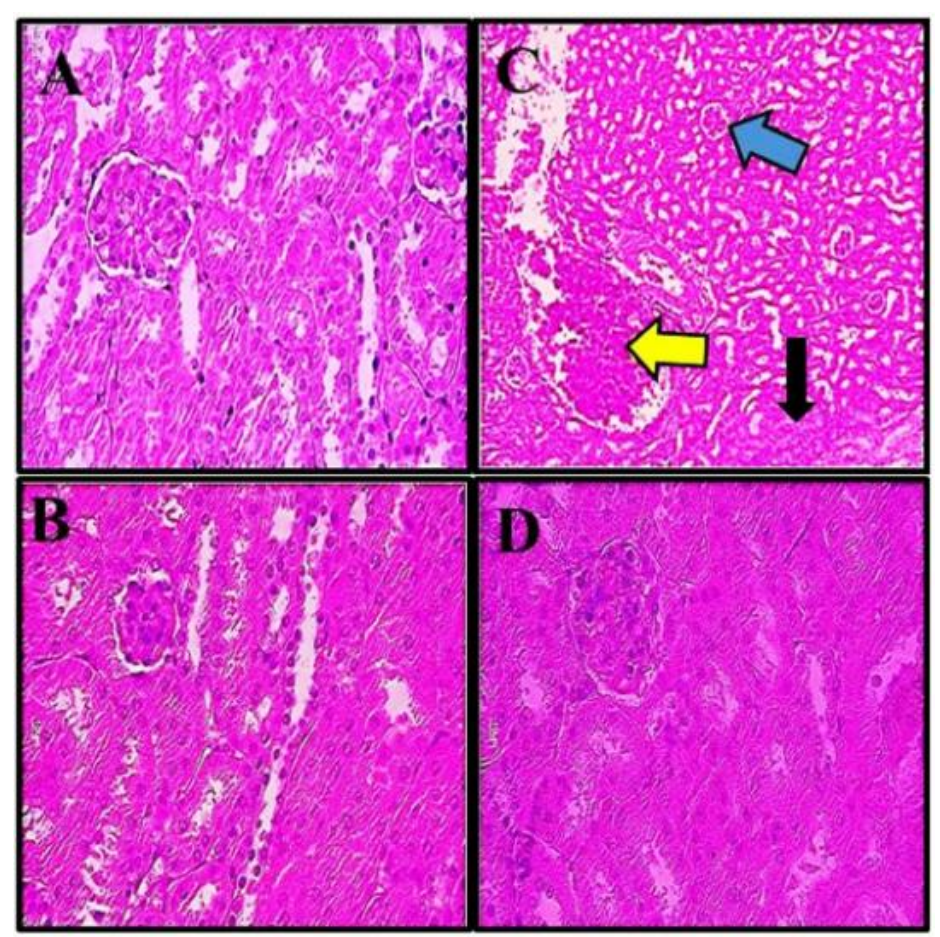

Figure 5. Histological changes of the kidneys (hematoxylin-eosin, $\times 100$ )

A, Normal kidney structure in the control (saline) group. B, Normal kidney structure in the group treated with genistein, $4 \mathrm{mg} / \mathrm{kg}$. C, More distributed leucocytes (black arrow), decrease the diameter of glomeruli (blue arrow), and enlargement of kidney veins (yellow arrow) in the morphine group. D, Normal kidney structure in the group treated with morphine plus genistein, $4 \mathrm{mg} / \mathrm{kg}$. 


\section{DISCUSSION}

The nicotine content of cigarettes has important biological impacts with a key role in the pathogenesis of kidney diseases (5). Genistein is an isoflavone and a phytoestrogen with different pharmacological effects (11). This study showed that morphine decreased the mice kidney and body weight while genistein increased them by applying protective effects. The studies of Lei et al., showed that morphine decreased kidney weight by damaging the kidneys and causing disorder in the body's metabolism (19). The effects of phytoestrogen compounds of the soy studied in animal models and human populations and their positive effects on the lipid profile improvement, including cholesterol have been reported (20). It has been shown that morphine reduces feeding, physical activity and digestive system function in animals (21). High doses of genistein stimulate the production of fat and cause an increase in the body weight (22). Genistein increases the weight and prevents weight loss in mice treated with methotrexate (23). In this study, morphine increased serum NO level, and genistein had no significant impact on the treated groups. This change in NOS occurs as a result of subsequent chronic administration of morphine mediated by opioid receptors, which is in agreement with the results of present study (10). Genistein inhibits tyrosine kinase which stimulates NO activity (25). In contrast with the results of our study, the studies of Santell et al. showed that administration of $20 \mathrm{mg} / \mathrm{kg}$ genistein increased nitric oxide production (24). This contradiction may be due to the use of high doses of genistein in Santell's study and low doses in this experiment. Evolution of glomeruli diameter and number in the experimental groups showed a significant increase in size and a significant reduction in glomerular number in the morphine group, while administration of genistein at $4 \mathrm{mg} / \mathrm{kg}$ before morphine administration significantly increased the glomeruli number. In this study, cellular infiltration was observed which was accompanied by an increase in Bowman's capsule space and blood cells in the renal tubules. Since the glomerular filtration rate depends on the number, diameter and continuity of these components, reducing glomeruli number and diameter can be associated with kidney dysfunction (27). Therefore, it can be concluded that administration of morphine makes significant changes in kidney glomerular morphology. In this study, increasing glomeruli diameter in the morphine group may indicate early kidney pathological changes. The results of this study indicated that genistein decreased damage to glomerulus by reducing blood pressure and renal nitric oxide production, induced by morphine. Oxidative stress and lipid peroxidation caused by oxygen free radical formation are involved in renal tissue damage (28). Morphine induces the production of reactive oxygen species (ROS) and superoxide by macrophages and mesonephric cells and damages kidney cellular DNA (29). On the other hand, animal studies have shown that antioxidants have the ability to remove free radicals (30). In this regard, Sung et al. reported that genistein reduced ROS production and apoptosis in groups receiving cisplatin by regulating p53 induction in kidney (31). In line with the present study, the results of Loei et al., indicated that opium administration to rabbits caused collecting tubes dilatation, interstitial tissue expansion along with severe hyperemia, renal corpuscle hyperplasia and hypertrophy and urinary tubules degeneration (32). In relation with the benefits of soy consumption, it has been shown that soybean increases catalase activity and reduces kidney damage in nephrotic syndrome as well as proliferation of fibrosarcoma cells (29). In this study, biochemical results of BUN and creatinine level evaluation in blood serum showed that morphine increased BUN and creatinine level while genistein reduced them. Measurement of creatinine and BUN is considered a standard factor in kidney function (33). Increasing BUN level induces oxidative stress and reduces antioxidant levels in the body (34). Antioxidant compounds have an inhibitory effect on cytochrome $\mathrm{P}_{450}$ and prevent morphine metabolism, thereby reducing the production of free radicals (35). LDH is an intracellular enzyme which exists in many body tissues, including heart, liver, kidney, blood and skeletal muscle and can be used as a marker for cellular damage evaluation (36). The studies of Samarghandian et al. showed that morphine significantly increased LDH serum level (37). It can be concluded from this study that genistein has positive effects on kidney tissue structure, LDH, creatinine and BUN (38).

\section{CONCLUSION}

The present study showed that genistein can significantly improve some of kidney damages against the destructive effects of morphine in mice. The results also suggest the potential effects of genistein especially antioxidant effects against toxic effects of morphine. Genistein may provide a novel therapeutic approach.

\section{ACKNOWLEDGEMENTS}

We gratefully acknowledge the Research Council of Kermanshah University of Medical Sciences (no: 93495) for the financial support. This work was performed in partial fulfillment of the requirements for MD of Amir Rasolimoghadam in faculty of medicine, Kermanshah University of Medical Sciences, Kermanshah, Iran.

\section{REFERENCES}

1. Seth P, Scholl L, Rudd RA, Bacon S. Overdose deaths involving opioids, cocaine, and psychostimulants-United States, 2015-2016. Am J Transplant. 2018;18(6):1556-68. https://doi.org/10.1111/ajt.14905

2. Jalili C, Ahmadi S, Roshankhah S, Salahshoor M. Effect of Genistein on reproductive parameter and serum nitric oxide levels in morphine-treated mice. Int J Reprod Biomed. 2016;14:95. https://doi.org/10.29252/ijrm.14.2.95

3. Pert CB, Snyder SH. Opiate receptor: demonstration in nervous tissue. Science. 1973;179(4077):1011-4. https://doi.org/10.1126/science.179.4077.1011 PMid:4687585

4. Salahshoor MR. Protective effect of crocin on liver toxicity induced by morphine. Res Pharm Sci. 2016;11:120.

5. Desmedt S, Spinewine A, Jadoul M, Henrard S, Wouters D, Dalleur O. Impact of a clinical decision support system for drug dosage in patients with renal failure. Int J Clin Pharm. 2018;21:1-9. https://doi.org/10.1007/s11096-018-0612-1 PMid:29785684

6. Ahmadnia H, Ghanbari M, Moradi MR, Khaje-Dalouee M. Effect of cigarette smoke on spermatogenesis in rats. $J$ Urol. 2009;4(3):159-63. 
7. Mercadante S, Arcuri E. Opioids and renal function. The Journal of Pain 2004;5(1):2-19. https://doi.org/10.1016/ j.jpain.2003.09.007 PMid:14975374

8. Jalili C, Tabatabaei H, Kakaberiei S, Roshankhah S, Salahshoor MR. Protective role of Crocin against nicotine induced damages on male mice liver. Int J Prev Med. 2015;6:92. https://doi.org/10.4103/2008-7802.165203 PMid:26442615 PMCid:PMC4593238

9. Gibanananda RS. Oxidants, antioxidants and carcinogenesis. Indian J Exp Biol 2002;40:1213-32.

10. Zarrindast M, Delphi L. Morphine-induced Nitric Oxide Production in PC12 Cells. Arch Iran Med. 2012;15:404-8.

11. Dolinoy DC, Weidman JR, Waterland RA, Jirtle RL. Maternal genistein alters coat color and protects $A$ vy mouse offspring from obesity by modifying the fetal epigenome. Environ Health Perspect. 2006:567-72. https://doi.org/ 10.1289/ehp.8700 PMid:16581547 PMCid:PMC1440782

12. Salahshoor MR, Roshankhah S, Hosseni P, Jalili C. Genistein Improves Liver Damage in Male Mice Exposed to Morphine. Chin Med J 2018;131:1598-604. https://doi.org/10.4103/ 0366-6999.235117 PMid:29941714 PMCid:PMC6032674

13. Choi M, Jung U, Yeo J, Kim M, Lee M. Genistein and daidzein prevent diabetes onset by elevating insulin level and altering hepatic gluconeogenic and lipogenic enzyme activities in non - obese diabetic (NOD) mice. Diabetes Metab Res Rev. 2008;24(1):74-81. https://doi.org/10.1002/ dmrr.780 PMid: 17932873

14. Rajaram S. The effect of vegetarian diet, plant foods, and phytochemicals on hemostasis and thrombosis. Am J Clin Nutr. 2003;78(3):552S-8S. https://doi.org/10.1093/ajcn/ 78.3.552S PMid: 12936949

15. Dattner AM. From medical herbalism to phytotherapy in dermatology: back to the future. Dermatologic therapy. 2003;16(2):106-13. https://doi.org/10.1046/j.1529-8019. 2003.01618.x PMid:12919112

16. Jalili C, Salahshoor MR, Hoseini M, Roshankhah S, Sohrabi $M$, Shabanizadeh A. Protective Effect of Thymoquinone Against Morphine Injuries to Kidneys of Mice. Iran J Kidney Dis. 2017;11(2).142-150

17. Salahshoor M, Mohamadian S, Kakabaraei S, Roshankhah $\mathrm{S}$, Jalili C. Curcumin improves liver damage in male mice exposed to nicotine. J Tradit Complement Med. 2016;6:17683. https://doi.org/10.1016/j.jtcme.2014.11.034 PMid:27114942 PMCid:PMC4833467

18. Roshankhah Sh, Salahshoor MR, Jalili F, Karimi F, Sohrabi $M$, Jalili C. Crocin effects on the nicotine-induce ovary injuries in female rat. Int J Life Sci. Pharma 2017;7:1-8.

19. Lei L, Liu S, Li Y, Song H, He L, Liu Q, et al. The potential role of glucokinase activator SHP289-04 in anti-diabetes and hepatic protection. European journal of pharmacology. 2018 May 5;826:17-23. https://doi.org/10.1016/ j.ejphar.2018.02.036 PMid:29477658

20. Muangman V, Cherdshewasart W. Clinical trial of the phytoestrogen-rich herb, Pueraria mirifica as a crude drug in the treatment of symptoms in menopausal women. Siriraj Medical Journal. 2018;53(5):300-9.

21. Yoshida S, Tajiri T, Yahara T, Yoshizumi T, Tanaka K, Muraoka $\mathrm{T}$, et al. Administration of opiate receptor antagonist inhibits mucosal atrophy of the gut in fasting rats. J Surg Res. 2000;93(1):177-81. https://doi.org/ 10.1006/jsre.2000.5970 PMid:10945961
22. Heim M, Frank O, Kampmann G, Sochocky N, Pennimpede $T$, Fuchs $P$, et al. The phytoestrogen genistein enhances osteogenesis and represses adipogenic differentiation of human primary bone marrow stromal cells. Endocrinology. 2004;145(2):848-59. https://doi.org/10.1210/en.2003-1014 PMid:14605006

23. King TJ, Shandala T, Lee AM, Foster BK, Chen K-M, Howe PR, et al. Potential effects of phytoestrogen genistein in modulating acute methotrexate chemotherapy-induced osteoclastogenesis and bone damage in rats. Int J Mol Sci. 2015;16(8):18293-311. https://doi.org/10.3390/ijms160818 293 PMid:26258775 PMCid:PMC4581246

24. Santell RC, Chang YC, Nair MG, Helferich WG. Dietary genistein exerts estrogenic effects upon the uterus, mammary gland and the hypothalamic/pituitary axis in rats. Int J Nutr. 1997 Feb 1;127(2):263-9. https://doi.org/ 10.1093/jn/127.2.263 PMid:9039826

25. Rezazadeh H, Kahnouei MH, Hassanshahi G, Allahtavakoli M, Shamsizadeh A, Roohbakhsh A, et al. Regulatory effects of chronic low-dose morphine on nitric oxide level along with baroreflex sensitivity in two-kidney one-clip hypertensive rats. Iran J Kidney Dis. 2014;8(3):194.

26. Liu D, Homan LL, Dillon JS. Genistein acutely stimulates nitric oxide synthesis in vascular endothelial cells by a cyclic adenosine 5'-monophosphate-dependent mechanism. Endocrinology. 2004;145(12):5532-9. https://doi.org/10.1210/en.2004-0102 PMid:15319357

27. Leffel EK, Wolf C, Poklis A, White KL. Drinking water exposure to cadmium, an environmental contaminant, results in the exacerbation of autoimmune disease in the murine model. Toxicology. 2003;188(2):233-50. https://doi.org/10.1016/S0300-483X(03)00092-1

28. Atici S, Cinel I, Cinel L, Doruk N, Eskandari G, Oral U. Liver and kidney toxicity in chronic use of opioids: an experimental long term treatment model. Journal of biosciences. 2005;30(2):245-252. https://doi.org/10.1007/ BF02703705 PMid:15886461

29. Javanbakht $M H$, Sadria R, Djalali $M$, Derakhshanian $H$, Hosseinzadeh $\mathrm{P}$, Zarei M, et al. Soy protein and genistein improves renal antioxidant status in experimental nephrotic syndrome. Nefrologia. 2014;34(4):483-90.

30. Santell RC, Chang YC, Nair MG, Helferich WG. Dietary genistein exerts estrogenic effects upon the uterus, mammary gland and the hypothalamic/pituitary axis in rats. The Journal of nutrition. 1997;127(2):263-9. https://doi.org/10.1093/jn/127.2.263 PMid:9039826

31. Sung MJ, Kim DH, Jung YJ, Kang KP, Lee AS, Lee S, et al. Genistein protects the kidney from cisplatin-induced injury. Kidney international. 2008;74(12):1538-47. https://doi.org/10.1038/ki.2008.409 PMid:18716605

32. Loei MA, Mami S, Parviz SA. The effect of the opium addiction on histological structure of liver and kidney in rabbits. 2013:32-45.

33. Lyman J. Blood urea nitrogen and creatinine. Emergency medicine clinics of North America. 1986;4(2):223-33.

34. Hall AM, Unwin RJ. The not so 'mighty chondrion': emergence of renal diseases due to mitochondrial dysfunction. Nephron Physiology. 2006;105(1):p1-p10. https://doi.org/10.1159/000096860 PMid:17095876 
35. Zaragoza A, Andrés D, Sarrión D, Cascales Ma. Potentiation of thioacetamide hepatotoxicity by phenobarbital pretreatment in rats. Inducibility of FAD monooxygenase system and age effect. Chemico-Biological Interactions. 2000;124(2):87-101. https://doi.org/10.1016/S0009-2797 (99)00147-7

36. Khodadadi S, Naghsh N, Mashayekh A. Effects of Silver Nanoparticle on Phosphocreatine kinase and Histological Changes of Skeletal Muscle Tissue in Male Wistar Rat. J Mazand Univ Med Sci. 2013;23(97):36-41.
37. Samarghandian S, Afshari R, Farkhondeh T. Effect of longterm treatment of morphine on enzymes, oxidative stress indices and antioxidant status in male rat liver. Int $\mathrm{J}$ Clin Exp Med. 2014;7(5):1449-53.

38. Shahsavar F, Ghanadi K, Jafarzadeh M, Nasiri B, Forutani $\mathrm{SH}$. Opium addiction decreases T3 uptake amount. Life Science Journal. 2013; 10(5s):608-10. 